Another emerging subject was that related to resources needed to maintain a scientific publication, in some cases supported by the Scientific Societies to which they belong, in others, by the advertising of medicines, supplies or medical equipment, and in some others even by the contribution of the same authors who want to have their articles published.

The transition from paper publications to electronic formats, for ecological, practical and economical reasons is a reality, ${ }^{4}$ but it also implies a challenge to obtain resources through advertising. Paper lasts, it can be seen. Electronic publications seem short-lived. However, society is heading toward this change, toward new ways of communicating.

Free access to scientific knowledge is a universal claim. Open access journals fulfill this "solidarity" role of sharing knowledge with the community. But material aspects are part of daily life. Although it is not a pleasant subject, in economically difficult situations, it may be possible that authors are asked for their contribution to face the costs related to the editorial process or, for example, the translations into other languages.

As we can see, a scientific publication is a craftwork tailored to the community it belongs to. That is what defines the extent of its objectives, but one should always aspire to excellence, out of respect for the work of the authors and editors and the trust that readers place in it.

At the end of the meeting of editors, we all felt that we had received a lot, perhaps much more than what we were able to give back by sharing our experiences, difficulties, ways of overcoming them, future projects and new challenges. Each of the journals has paved the way for the rest. We hope to meet next year with the same enthusiasm and commitment.

Norma Elena Rossato, M.D. Associate Editor

http:/ / dx.doi.org/10.5546/ aap.2018.eng.2

To cite: Rossato NE. Pediatric journals of the Southern Cone. Similarities and differences. Arch Argent Pediatr 2018;116(1):2-3.

\section{REFERENCES}

1. ICMJE. Recomendaciones parala preparación, presentación, edición y publicación de trabajos académicos en revistas médicas. Rev Esp Salud Pública. 2017;91. [Accessed on 1103-2017]. Available at http://www.icmje.org/recommendations/ translations/spanish2016.pdf

2. Rueda-Clausen Gómez CF, Villa-Roel Gutierrez C, RuedaClausen Pinzón CE. Indicadores bibliométricos: origen, aplicación, contradicción y nuevas propuestas. MedUNAB 2005; 8(1);29-36. [Accessed on 11-03-2017]. Available at: http://132.248.9.34/hevila/Medunab/2005/vol8/no1/5.pdf

3. Ferrero F. Publicación científica: ¿Cómo enfrentar el rechazo? Arch Argent Pediatr 2015;113(2):98-100.

4. Gómez Rodríguez G, Gallo Estrada MC. El proceso de transición de las revistas académicas: de impreso a digital. Paakat: Revista de Tecnología y Sociedad. Año 6, Núm. 10, marzo-agosto 2016. [Accessed on 11-03-2017]. Available at: http://www.udgvirtual.udg.mx/paakat/index.php/paakat/article/ view/265

\title{
Editors of biomedical journals and the disclosure of their own conflicts of interest
}

Continuing with the topic of conflicts of interest related to scientific publications, recently, an article by Liu et al. ${ }^{1}$ was published in the British Medical Journal (BMJ) regarding the financial relations of medical journal editors. According to this investigation, in the USA, approximately half of the editors of 52 prestigious medical journals received financial payments from the pharmaceutical industry and medical device manufacturers in 2014.

Recently, in a special article ${ }^{2}$ published in Argentine Archives of Pediatrics (Archivos Argentinos de Pediatria) with regard to a publication supplement in the Journal of the American Medical Association (JAMA) devoted to conflicts of interest, the complex topic of conflicts of interest was extensively approached in different scenarios: real conflicts or perceived by physicians, investigators, professional associations, scientific societies, biomedical journals among other stakeholders.

The objective of the observational and retrospective study by Liu et al., ${ }^{1}$ was to estimate the financial payments from industry to US journal editors. Two medical editors (editors in chief or associate editors) were selected from 52 journals drawn from 26 specialties, with a high impact factor for their specialty. General and research payments received from pharmaceutical companies and medical device manufacturers were collected and examined in 2014, through the Open Payments databases. Additionally, the magnitude of such payments was compared across journals and by specialty, and journal websites were also reviewed 
to determine if conflict of interest policies for editors were readily and publicly accessible.

Out of the 713 eligible editors, 361 (50.6\%) received research payments in 2014 . The highest general payments received by journal editors were from endocrinology, cardiology, gastroenterology, rheumatology and urology. Payments were higher for those specialties that rely on expensive devices (cardiology, orthopaedics). Conflict of interest policies were easily accessible (within the first five minutes of search) for 17 out of the $52(32.7 \%)$ journals.

Authors conclude that "Industry payments to journal editors are common and often large, particularly for certain subspecialties. Journal editors should consider again conflict of interest policies and the impact that the editor's relations with industry might have on public trust in published research".

Authors of the article, by means of a very accurate methodology, performed a detailed analysis of the situation of medical editors of influential scientific publications regarding payments and commercial interests with the industry. This paper, according to the authors, is the first one examining industry payments to physicians that pharmaceutical companies should disclose in the publicly available database Open Payments.

Open Payments is a US federal program required by the Affordable Care Act, that collects information about general payments that pharmaceutical and device companies make to physicians and teaching hospitals for issues like travel, meals, gifts, speaking fees and research. It also includes ownership interests (shares or others) that physicians or their immediate family members have in these companies. This information is made available to the public each year on the website. ${ }^{3}$

Payments to editors ranged from low amounts or none to figures as high as 10 million dollars. Besides, it was found that only $30 \%$ of the journals included in the study had published editorial policies for conflicts of interest readily accessible in their website. Moreover, even when policies were available they were variable. It was also noted that one journal (Anesthesiology) had a conflict of interest policy which was so detailed and accessible that could serve as an example. ${ }^{1}$

Among publication policies or regulations of most of biomedical journals, authors of studies published should disclose their sources of funding and other conflict of interests related to their study. Likewise, reviewers are requested to declare if they have conflicts of interest for each particular article. However, and only recently, the subject of disclosing conflicts of interest of editors (in chief, associate/assistant) of scientific publications is being examined.

It is recognized that there might be the possibility of bias during the process of review and/or publication. Certain predisposition in favor or against about a manuscript publication might be influenced by commercial and/or personal interests.

The adequate procedure would be to avoid any situation that might lead to a conflict of interest, even an apparent and/or potential conflict. But nobody is exempt from a potential conflict. One should not prejudge. Weschler (several years ago) in an editorial on this topic mentioned a conclusive statement by Richard Smith, former editor of the BMJ who said that "Conflict of interest is a condition, not a behavior". ${ }^{4}$

Hence, having conflicts of interest is not a harmful or detrimental act. The problem is not to have conflicts; the problem is concealment.

The International Committee of Medical Journal Editors (ICMJE) states that the final determination about the publication of an article should not be influenced by any type of conflicts. ${ }^{5}$ However, this is not standardized. Each journal should formulate and implement policies for the disclosure of conflicts of interest necessary to ensure, as far as possible, editorial transparency. At present, honesty of all parties involved seems to be the most adequate policy.

Adriana Aguilar, M.D. Assistant Editor

http:/ / dx.doi.org/10.5546/aap.2018.eng.3

To cite: Aguilar A. Editors of biomedical journals and the disclosure of their own conflicts of interest. Arch Argent Pediatr 2018;116(1):3-4.

\section{REFERENCES}

1. LiuJJ,BellCM,MatelskiJJ, etal.PaymentsbyUSpharmaceutical and medical device manufacturers to US medical journal editors: retrospective observational study. BMJ 2017;j4619. DOI: $10.1136 /$ bmj.j4619

2. Serra ME. Conflictos de interés: claroscuros entre los principios y el fin. Arch Argent Pediatr 2017;115(5):501-504.

3. Centers for Medicare and Medicaid Services. Open payments. [Accessed on: November $20^{\text {th }}, 2017$ ]. Available at: https: / / www.cms.gov/ openpayments /

4. Wechsler AS. What's a journal to do? J Thorac Cardiovasc Surg 2006;131:771-2.

5. International Committee of Medical Journal Editors. Recommendations for the Conduct, Reporting, Editing, and Publication of Scholarly work in Medical Journals. [Accessed on: November 20 $0^{\text {th }}$, 2017]. Available at: http:/ / www.icmje.org/recommendations / 